\title{
11
}

\section{Diplomacy in the 1990s: Issues for the Washington embassy}

\author{
James Cotton
}

The 1990s was a period in Australian foreign relations and diplomacy book-ended by two major geopolitical events: at the beginning, the destruction of the Berlin Wall and the collapse of socialism in Eastern Europe (though at the same time its resurgence in China), and at the end, the terrorist attacks of September 11. The former led to what appeared to comprise an entirely new international environment, opening the way for many diplomatic and regional initiatives; the latter, according to Richard Clarke's memoir, was hardly anticipated even at the highest levels in Washington, ${ }^{1}$ and thus raised problems for a future time, and especially for Prime Minister John Howard who was physically present.

This chapter reviews the policy responses of successive Australian Governments to these major changes in the environment, paying particular attention to their consequences for relations with the United States. These policies need to be outlined at the outset since, with the ease of communications and the frequent practice of visiting personal diplomacy by members of government, the activities of ambassadors were highly constrained by the priorities of Canberra. The chapter

1 Richard Clarke, Against All Enemies: Inside America's War on Terror, Free Press, New York, 2004. On Australia and the end of the Cold War era, see Coral Bell (ed.), Agenda for the Nineties: Australian Choices in Foreign and Defence Policy, Longman Cheshire, Melbourne, 1991; Stuart Harris and James Cotton (eds), The End of the Cold War in Northeast Asia, Lynne Rienner, Boulder, 1991. 
subsequently considers the personnel and work of the Australian embassy in Washington, drawing upon such materials as are available on the public record.

\section{The 1990s transition in Australian diplomacy: The Hawke and Keating governments}

While any starting point can be seen as arbitrary, and one defined by date is almost bound to be so, it will be argued here that the 1990s in Australian foreign policy began in the final two months of 1989 with the appearance of two landmark texts, both of which sought to redefine Australia's approach to Asia. Both carried major implications for the future place of the US and for the alliance in Australian diplomatic calculations. To some extent they may be seen as bids for policy space, given that in the bilateral relationship with the US, defence and Defence ministers had become principal focus and actors respectively.

The Garnaut Report-Professor Ross Garnaut had been Hawke's principal economic adviser and then Ambassador to China - was prepared on prime ministerial direction to outline national policies appropriate for the rise of Asia. It described an era in which the further development of the Northeast Asia economies would draw Australia into their trading and investment orbits, provided that sufficient domestic reforms were enacted to maximise the opportunities presented. ${ }^{2}$ The notion that at some future time Australia might be required to 'choose' between the US and China was hardly to be anticipated, and in general Garnaut assumed that these economies would prosper to the extent that they liberalised, and economic liberalisation would bring social and ultimately political freedoms in its train. Garnaut thus anticipated, in light of the transformation of the Soviet bloc, that Marxist authoritarianism in China would fade and, accordingly, that North Korea would either reform or experience isolation and irrelevance.

A month after the Garnaut Report, Foreign Minister Gareth Evans delivered a ministerial statement on Australia's regional security. Its focus was principally upon Southeast Asia, where Evans declared

2 Ross Garnaut, Australia and the Northeast Asian Ascendancy: Report to the Prime Minister and the Minister for Foreign Affairs and Trade, Australian Government Publishing Service, Canberra, 1989. 
Australia was moving beyond the conventional security preoccupations and anxieties of former times to a more confident era of 'comprehensive engagement'. While the text did address powers and regions beyond the immediate Australian environment, its message was that though the US remained 'the strongest player', Washington's focus was bound to shift from geopolitical to economic concerns. Moreover, in the longer term, the US would also find itself in a world in which in relative terms other powers, notably the European Union and Japan, would play a more prominent role. ${ }^{3}$

Taken together, these texts delivered mixed messages. ${ }^{4}$ Both agreed that, in the calculations of states, geopolitical considerations were giving way to economic concerns and to a great extent security was taking on a multidimensional aspect to include economic and social means as well as ends. However, if Garnaut was right that Australia's main game was in Northeast Asia, then Evans' evident preoccupation with Southeast Asia was misplaced and perhaps even somewhat old-fashioned, especially given that his statement made no secret not only of Australia's economic standing but also its technological edge in conventional force capabilities. To be strictly accurate, of course, Garnaut's text was not a direct statement of policy, though Prime Minister Bob Hawke's remarks on its launch suggested many of its recommendations would be followed, and indeed on that occasion he announced initiatives that directly implemented some of them. ${ }^{5}$ More were soon to follow.

Nevertheless, the implications for Australia's relations with the US were clear from both documents. If economics trumped security, and if Australia's economic future lay in Northeast Asia, then the US would matter less in two respects. Important aspects of the security alliance would be outmoded, and over time whatever the volume of Australia's trade and investment links with the US they would grow less important. Commentators at the time recognised the former: according to the remarks of Russell Trood at a 1996 workshop, 'Australia's security dependence on Washington has declined appreciably over the last

3 Gareth Evans, 'Australia’s Regional Security', Ministerial Statement, Department of Foreign Affairs and Trade, Canberra, 1989.

4 Nancy Viviani, 'Of Voices, Visions and Texts', in Greg Fry (ed.), Australia's Regional Security, Allen \& Unwin, Sydney, 1991, pp. 22-31.

5 Australian Government Department of the Prime Minister and Cabinet, Speech by the Prime Minister: Launch of the Garnaut Report 'Australia and the Northeast Ascendancy' Sydney, (Robert Hawke), 22 November 1989, pmtranscripts.pmc.gov.au/release/transcript-7826. 
twenty years' ${ }^{6}$ It should be recalled that the security context for this observation was the East Asia Strategy Initiative, which led to an appreciable downsizing of US military deployments in Asia. The launch of Asia-Pacific Economic Cooperation (APEC) in 1989 may be seen, in part, as preparation for the eventuality of a diminishing US economic impact on Australia. APEC was designed to facilitate the economic complementarity and potential of the Western Pacific rim that was Garnaut's focus, while providing an alternative trade vehicle if the Canada-US Free Trade Agreement (FTA - negotiated in 1987) provided a successful foundation for a North American Free Trade Agreement (NAFTA) (subsequently agreed in 1993) or an FTA embracing all of the Americas, turning the US away from the region. At the time the inward-looking nature of the European Union was taken as a given.

Under Paul Keating, APEC became the centrepiece of the government's pursuit of regional enmeshment. And from the first he strenuously sought to involve the US. It should be recalled that in its original conception, the proposed membership of APEC excluded the US, although then Secretary of State James Baker persuaded Prime Minister Hawke to extend an invitation to Washington for the inaugural meeting in Canberra. ${ }^{7}$ Even with the emergence of APEC as a major architectural advance in the region, the 1990s remained, beyond the conclusion of the Uruguay Round of the General Agreement on Tariffs and Trade (GATT), a decade of trade tensions.

President George HW Bush visited Australia in 1991. Expecting nothing more taxing than golf with Bob Hawke, he found himself instead in an intense and somewhat one-sided briefing on the issue of regional architecture with the new prime minister. According to Paul Kelly's account, after Keating had expounded to the President his vision for the US to shift its emphasis from the Atlantic to leadership in the Pacific, Bush's National Security Adviser Brent Scowcroft remarked that this was an idea that the US was yet to formulate even for itself. ${ }^{8}$ Nevertheless, the ideas floated at their meeting led to the establishment of the Australian American Leadership Dialogue.

\footnotetext{
6 Russell Trood, 'The Australian-American Alliance: Beyond Demystification', in William Tow, Russell Trood, Toshiya Hoshino (eds), Bilateralism in a Multilateral Era, Japan Institute of International Affairs \& Centre for the Study of Australia-Asia Relations, Tokyo, 1997, p. 135.

7 James A Baker III, The Politics of Diplomacy: Revolution, War and Peace, 1989-1992, Putnam's Sons, New York, 1995, pp. 609-13.

8 Paul Kelly, The March of the Patriots: The Struggle for Modern Australia, Melbourne University Press, Melbourne, 2009, p. 161.
} 
One of the innovations Keating proposed was a regional heads of government conclave. ${ }^{9}$ This idea, which Keating pressed on both Bush and Bill Clinton, transformed APEC from a second-tier and somewhat experimental forum to a major focus for regional diplomacy. Keating was fulsome and no doubt accurate in his claims for being the originator of this innovation - on his account, Bush remained unconvinced, but Clinton grasped the opportunities presented - however, Clinton's memoirs, in which Keating is not mentioned, assert it was his own idea. ${ }^{10}$

Consistent with his December 1989 Security Statement and with the government's emphasis upon building regional structures, Gareth Evans pursued the idea of an Asia-Pacific-wide security dialogue on the lines of the Commission on Security and Cooperation in Europe. He aired this proposal at an Association of Southeast Asian Nations (ASEAN) post-ministerial in Jakarta in 1990, and in a subsequent opinion piece. ${ }^{11}$ The initial American reception was hostile. While by this time there was acceptance of regionalism as a benign economic mechanism, security initiatives of this kind were seen as simply serving the Soviet objective of constraining US power, and Secretary of State James Baker told Evans so. ${ }^{12}$ However, with the collapse of the Soviet Union, Baker came around to the idea by $1992 .{ }^{13}$

Evans went so far as to formulate - with a little help from his department and academic advisers - a new approach to security, 'co-operative security', which seemed to portend an era where a change in state norms of behaviour, new collective regimes, and a strengthened UN system would be able to head off or remediate most forms of conflict. Evans' book had little to say on exactly what role the US might play in this new world arrangement beyond noting that the management of the world's multiform security challenges was beyond even America's resources as the sole superpower. ${ }^{14}$ The overview of Australia's foreign policy he had published (with Bruce Grant) in 1991 was a little more forthcoming,

9 Paul Keating, Engagement: Australia Faces the Asia-Pacific, Pan Macmillan, Sydney, 2000, p. 195.

10 Keating, Engagement, pp. 29-30, 82, 86-93; Bill Clinton, My Life, Knopf, New York, 2004, pp. 560-1, 930 .

11 Gareth Evans, 'What Asia Needs is a Europe-Style CSCA', International Herald Tribune, 27 July 1990.

12 James A Baker to Australian Foreign Minister, Senator Gareth Evans, 19 November 1990, published in 'Security, in letter and spirit', The Australian Financial Review, 2 May 1991, p. 24.

13 James A Baker, 'America in Asia: Emerging Architecture for a Pacific Community', Foreign Affairs, vol. 70, no. 5, 1991/92, pp. 1-18.

14 Gareth Evans, Cooperating for Peace: The Global Agenda for the 1990s and Beyond, Allen \&Unwin, Sydney, 1993, p. 5. 
though it devoted twice as much space to Southeast Asia alone. This text cautioned against regarding the US as in any way exceptional: 'Impressive though its achievements and authority are, the United States is not so much an all-powerful force as a nation like any other, with interests like any other, and domestic pressures upon it to act ... like any other. ${ }^{15}$ Perhaps indicative of a cooling in relations, the 1993 AustraliaUS Ministerial Consultations (AusMin) due to be hosted by Australia was delayed until March 1994. In a diplomatic forum that began with security and foreign policy in mind, the communiqués of which were otherwise predictable platitudes regarding closeness of world views and values, from 1990 successive American delegations had been required also to defend their use of subsidies for primary produce exports and to acknowledge - if tacitly - the potential damage posed by this practice to Australian exports of like commodities. ${ }^{16}$

In the immediate neighbourhood, the Agreement on Maintaining Security with Indonesia, negotiated in great secrecy, was signed in December 1995. By this time a number of commentators were of the view that the distance between Australia and the US was growing, and correspondingly that the alliance was diminishing in importance as the web of regional security linkages grew more complex. ${ }^{17}$ However, a note of caution is in order in summarising the trends under the Hawke and Keating governments. The various strategic overviews proceeding from the defence establishment, as might be expected, alerted policymakers to the risks and dangers in the new environment while still stressing the many advantages to Australia of the Australia, New Zealand, United States Security Treaty (ANZUS) and its associated arrangements.

\section{The Howard Government}

Although foreign policy was not a significant factor in the change of government in 1996, the Coalition made clear during the election campaign of that year that they would bring a different style to

15 Gareth Evans and Bruce Grant, Australia's Foreign Relations in the World of the 1990s, Melbourne University Press, Melbourne, 1991, pp. 302-3.

16 For AusMin documents see dfat.gov.au/geo/united-states-of-america/ausmin/pages/ausminaustralia-united-states-ministerial-consultations.aspx.

17 Roger Bell, 'Reassessed: Australia's Relationship with the United States', in James Cotton and John Ravenhill (eds), Seeking Asian Engagement: Australia in World Affairs 1991-95, Oxford University Press and AIAA, Melbourne, 1997, pp. 207-29. 
its management. The touchstone for policy would be its service of 'the national interest', which was understood to mean Australia's physical security and prosperity, and the safety of its citizens. In addition, the Coalition proposed a 'reinvigoration' of the US alliance, claiming that 'Asia' had supplanted the American alliance in the management and prioritising of foreign policy. ${ }^{18}$ In its first month in office, the Coalition's commitment to the alliance was manifest in the supportive remarks made regarding the US decision to deploy major naval units as a response to Chinese missile tests in the waters off Taiwan - this tactic was evidently designed to pressure the Taiwanese who were conducting elections for the presidency. Beijing responded with a virtual freeze on relations that lasted into 1997.

The new government took advantage of the fact that they were the hosts of AusMin in July 1996 to place their stamp on the relationship. In a joint declaration, which was given the grandiloquent title, 'the Sydney Statement', they rehearsed what they regarded as the overwhelming value of the alliance:

Australia and the United States place enduring value on the alliance because of its significance in maintaining and consolidating Australia's capability for self-reliant defence, and because it constitutes a crucial element in the United States' permanent presence in the Asia Pacific region. Both governments reaffirm their commitment to that presence through forward-deployed US forces, access arrangements and exercises. We both attach importance to continuing Australian access to United States technology, close cooperation in intelligence matters, the assurance of resupply and logistics support in a crisis, and combined exercises and training to promote interoperability. ${ }^{19}$

The concrete outcomes of the AusMin meeting, however, were limited to the announcement of new joint training arrangements and the extension of the life of the joint intelligence facilities. Significantly, the 1996 communiqué included the observation that Australia 'welcomed'

18 James Cotton and John Ravenhill, 'Australia in World Affairs 1996-2000', in James Cotton and John Ravenhill (eds), The National Interest in a Global Era: Australia in World Affairs 1996-2000, Oxford University Press/AIIA, Melbourne, 2001, pp. 3-9.

19 AusMin, Australia-United States Ministerial Consultations: 1996 Sydney Statement, Department of Foreign Affairs and Trade, Canberra, 1996, dfat.gov.au/geo/united-states-of-america/ ausmin/Pages/australia-united-states-ministerial-consultations-1996-sydney-statement.aspx. 
the recent US-Japan agreement on alliance responsibilities; ${ }^{20}$ it also contained some remarks on trade, distinctly muted by comparison to the earlier communiqués of the decade.

The wider context of these sentiments was an effort by the US to revivify its Asian alliances, endeavouring to persuade its partners to assume further responsibilities not only for their own defence but also in relation to regional US priorities. Japan had already agreed to relax restraints upon what was always a somewhat one-sided relationship, being the product of exceptional historical circumstances. ${ }^{21}$ While the post-1990 draw-down of US forces in Asia was an encouragement to such a re-evaluation, both parties were mindful of the emergence of new China-Taiwan tensions and of the need to maintain vigilance given North Korea's admission of its pursuit of a nuclear program (the resulting crisis constrained temporarily as it turned out - by the 1994 'Agreed Framework').

The new government then turned its attention to drafting a foreign policy White Paper that further signalled the essentials of its distinctive style: not only would national interest - conceived in somewhat constrained security and economic terms as well as with reference to certain 'values' - henceforth constitute the standard for national policy, but a priority would be placed on bilateral strategies. Bilateralism was described as 'the basic building block', ${ }^{22}$ and it would take the place of the previous government's (allegedly excessive) enthusiasm for multilateralism. While the White Paper devoted a good deal of attention to Asia - some of its projections soon undermined by the regional financial crisis - the US was identified as a member of the nation's most important partnerships and one the government was determined to broaden and strengthen, including in relation to joint participation in Asian regional institutions. The White Paper conceded that while the US was 'a key economic partner', nevertheless there remained the likelihood of differences continuing to appear in trade and trading strategies. Significantly, the document envisaged the emergence of Japan as 'a more important defence partner' in the context of the US alliance.

20 Tomohiko Satake, 'The origin of trilateralism? The US-Japan-Australia Security Relations in the 1990s', International Relations of the Asia-Pacific, vol. 11, no. 1, 2011, pp. 87-114.

21 Ministry of Foreign Affairs of Japan, The Japan-US Joint Declaration on Security, Alliance for the

$21^{\text {st }}$ Century, 17 April 1996, www.mofa.go.jp/region/n-america/us/security/security.html.

22 Department of Foreign Affairs and Trade, White Paper, In the National Interest: Australia's Foreign and Trade Policy, Department of Foreign Affairs and Trade, Canberra, 1997, p. 53. 
A reinvigorated alliance required more, however, than words. As Defense Secretary William Cohen noted at AusMin in 1998, Australia was the first power to volunteer forces to deal with the contingency generated by Saddam Hussein's threat to expel weapons inspectors. ${ }^{23}$ Yet at the same time Cohen was telling his Australian colleagues, if journalists' reports are accurate, that Australia was not spending sufficient funds on defence and there was only so much that the US could do for partners who did not equip themselves appropriately. ${ }^{24}$ However, the Howard Government only later began a significant and continuing augmentation of the defence budget as a response first to the East Timor commitment and then to the events of 2001.

Accordingly, US support for Australian intervention in the East Timor crisis of 1999 was crucial for the success of the International Force for East Timor (INTERFET). Yet in the days immediately following the independence ballot there were anxious moments in Canberra when the Clinton administration seemed reluctant to offer support for the intervention that was clearly needed in order to deal with the mayhem in the territory. The view was taken in the US that this crisis should receive an 'Asian' response, this position reflecting both the desire not to derail Indonesia's democratic transition and also the preoccupation with the Kosovo crisis. National Security Adviser Sandy Berger was reported as being opposed to any direct American role. ${ }^{25}$ In the event, as it became clear that INTERFET would have to become largely an Australian operation, American support was promised. En route to the Auckland summit of APEC, Clinton made it plain that Indonesia would suffer potentially severe financial penalties if cooperation in the deployment of a multinational force was not forthcoming. Though US troops would not be deployed, logistic and intelligence assets were mobilised, and Washington earmarked mobile forces to be available as reserves if called upon. Yet the initial fear that the US would choose to ignore Australia's articulated security concerns in the interests of better relations with the

23 Joint Press Conference at the Conclusion of the AusMin Talks with Secretary of State Madeleine K Albright, Secretary of Defense William Cohen, Australian Minister for Foreign Affairs Alexander Downer, and Australian Minister for Defence Ian McLachlan, HMAS Watson, Sydney, 31 July 1998.

24 Greg Sheridan, 'US warns of defence risk', Australian, 31 July 1998.

25 Sandy Berger, National Security Advisor, and Gene Sperling, National Economic Advisor, press briefing, 8 September 1999. On the East Timor issue, see James Cotton, East Timor, Australia and Regional Order: Intervention and its Aftermath in Southeast Asia, Routledge, London, 2004. 
major (and now democratising) Southeast Asian regional power recalled an earlier time when just this calculation was followed: the West New Guinea dispute of the early 1960 s. $^{26}$

From the American perspective, there was certainly the expectation that reciprocity could be expected from Australia in security crises. On a private visit to Australia in 1999, Richard Armitage - already a keen proponent of the project to remove Saddam Hussein, he would later progress as Deputy Secretary of State in the George W Bush Administration - asserted that if Australia did not participate with the US in a conflict over Taiwan, the alliance would be at an end. ${ }^{27}$ While this was a personal opinion, the readiness with which Australia subsequently became engaged first in Afghanistan and then Iraq was remarkable. In retrospect it is clear that no proper assessment was made of the likely costs or consequences, which suggests that the American lead was the crucial factor in these decisions. Yet it is perhaps unsurprising that, witnessing September 11 from the vantage point of Washington, John Howard invoked the ANZUS Treaty. Whether Keating would have taken this step, while a hypothetical, might be doubted; Hawke is more likely to have done so.

\section{The ambassadors: Michael Cook and Don Russell}

Australian emissaries to Washington have generally been either senior diplomats or political figures with Cabinet experience. At the beginning of the 1990s, Michael Cook held the position. Though a Cambridge man with more than three decades of experience in the department, Cook had not held the usual brace of ambassadorships of his peers (apart, significantly, from a 10-month sojourn in Saigon). The historical context of his movement to the position is of considerable relevance. In February 1985 Hawke, after significant public pressure, had withdrawn from an undertaking to the US to facilitate the testing of

26 Stuart Doran, 'Toeing the Line: Australia's Abandonment of "Traditional" West New Guinea Policy', Journal of Pacific History, vol. 36, no. 1, 2001, pp. 5-18.

27 William T Tow and Leisa Hay, 'Australia, the United States and a "China Growing Strong" Managing Conflict Avoidance', Australian Journal of International Affairs, vol. 55, no. 1, 2001, pp. 37-54; Greg Sheridan, 'What if bluff and bluster turn to biff?', Australian, 10 March 2000. 
nuclear-capable MX missiles in the Western Pacific. ${ }^{28}$ While Secretary of State George Shultz diplomatically facilitated this change of course, he and his colleagues were suspicious of the trend in Australian policy, especially in relation to nuclear weapons. In the same year, the initiative to construct a South Pacific Nuclear Free Zone (SPNFZ) was realised in the Treaty of Rarotonga and Australia also continued to campaign for a Comprehensive Test Ban Treaty (a measure finally realised in 1996 but which Washington has yet to ratify; neither had the US signed on to SPNFZ).

Cook was the next Hawke Government appointee to the position of Ambassador (following Rawdon Dalrymple, 1985-89). Having served as an adviser to Malcolm Fraser, Cook was Fraser's appointee in 1981 to become Director-General of Office of National Assessments (ONA) and thus the nation's most senior intelligence figure, a position he held until 1989. He was also a person of strong conservative views (as is still apparent from his published writings ${ }^{29}$ who prided himself on his closeness to important figures in the US Republican Party. According to one account, Cook while at ONA had raised with Justice Robert Hope, then reviewing the Australian intelligence community, the suggestion that Foreign Minister Hayden's suspicion of the US had obstructed information cooperation with Washington. ${ }^{30}$ As one journalist wrote at the time of his appointment, 'Some Foreign Affairs officials are concerned about what they describe as Mr Cook's conservative, proUS views'. ${ }^{31}$ It may be postulated that his appointment was intended to reassure Washington that Australia would not be taking the New Zealand route out of the alliance.

The appointment also indicated Hawke's close control of the relationship with the US; he was reported to have spent a good deal of time with Cook while he was at ONA. As Ambassador, Cook played a direct role in the events that led to the Australian commitment to the Gulf War. The key telephone call from Bush to Hawke on 10 August 1990 was made

28 Cabinet Minute, Security Committee, 29 January 1985, item A13979, series 4613/SEC, National Archives of Australia (NAA), Canberra.

29 Michael Cook, 'Why Australia Fights Other People's Wars', Quadrant, vol. 57, no. 9, 2013; also 'ANZUS and the Monroe Doctrine', Quadrant, vol. 57, no. 12, 2013; 'The American Alliance and the Shaping of the World', Quadrant, vol. 58, no. 4, 2014.

30 Brian Toohey and William Pinwill, Oyster: The Story of the Australian Secret Intelligence Service, Heinemann, Melbourne, 1989, p. 255.

31 Tom Burton and Helen O'Neil, 'It's musical chairs as diplomats are shuffled', Sydney Morning Herald, 25 November 1988, p. 7. 
as a result of a request from the Ambassador as intermediary. Though Hawke stated that his decision to commit forces to the Gulf stemmed from that conversation, it transpired that the decision had actually been taken the previous day by a small group of ministers. Cook was a central figure in the process whereby this decision was made. ${ }^{32}$

Nevertheless, not all members of the Cabinet were so impressed with Cook's appointment. It was alleged by journalists that the relationship between Evans and Cook was poor, with the Foreign Minister admonishing his envoy for his failure to develop sufficiently close relations with both sides of US politics, thus prejudicing Australia's interests when Clinton defeated Bush in the 1992 elections. It was noteworthy that Cook had decided not to attend that year's convention of the Democratic Party, though he was present at the Republican Party's equivalent. Indeed, notoriously media averse - diplomacy was certainly a different art at that time - rather than submit to an interview himself, Cook had recommended to an Australian journalist writing his profile to consult leading Republican security figures Douglas Paal and Richard Armitage for assessments of his role. In any event, the journalist came to the conclusion that from the point of view of Keating's agenda, Cook was out of step with the current government's worldview:

So for those in Canberra who are eager to see Australia stretching into new relationships in the region, in which the US is but one of many friends, rather than the special friend it's been, Cook is part of an old school that makes him the wrong man for the times. ${ }^{33}$

According to the Washington Post correspondent subsequently sent to Canberra, the Ambassador was known for offering 'not much availability' to the media. ${ }^{34}$ Nevertheless, Cook was not oblivious to the shifting emphases of Canberra's strategy. One of his rare forays into the American press took the form of a spirited defence of the efficiencies of the Australian sugar industry, pointing out the inequity perpetrated

32 Alan Ramsey, 'President Bob rolls over for a tickle', Sydney Morning Herald, 11 August 1990, p. 25; Paul Grigson, 'How we begged to go to the Gulf', Sydney Morning Herald, 1 September 1990; Bob Hawke, The Hawke Memoirs, Heinemann, Port Melbourne, 1994, pp. 511-20. On the Gulf commitment see Murray Goot and Rodney Tiffen (eds), Australia's Gulf War, Melbourne University Press, Melbourne, 1992.

33 Pilita Clark, 'Ambassador on the Warpath', Sydney Morning Herald, 11 March 1993, p. 13.

34 Kathleen Burns, comments at 'Don Russell address at the National Press Club on 9 March 1994'. See also Kathleen Burns, 'A Stranger in Paradise? A Foreign Correspondent's View of the Parliamentary Press Gallery', Papers on Parliament, No. 23, Australian Parliament House, Canberra, 1994, www.aph.gov.au/binaries/senate/pubs/pops/pop23/c03.pdf. 
by the GATT-inconsistent quotas placed in its way in the US market. ${ }^{35}$ He also defended Australia's refusal to offer rights of settlement to boat people found not to be genuine refugees, a practice that he argued should be seen in the context of the generous national refugee quota. ${ }^{36}$

Following Cook, the Keating Government appointed Don Russell, an economist and (still youthful) former career official, though from Treasury and not from External/Foreign Affairs as his bureaucratic predecessors had been. This appointment can be seen to reflect those specific regional priorities that Keating had espoused. As has been shown, Keating was especially concerned to secure the enthusiastic participation of the US in the emerging economic regionalism of the Asia-Pacific. ${ }^{37}$ It should be recalled that the trade priorities of the Clinton Administration at the outset were by no means clear, and in the circumstances, an envoy with a close knowledge of the relevant issues would be advantageous. In addition to his background, Russell had most recently worked very closely with Keating, becoming, in Neal Blewett's estimate, his 'most influential economic adviser'. ${ }^{38}$ In his memoir, Keating records Russell's personal role in convincing the American administration that APEC should involve a leaders' meeting; he also states that in Jakarta, Clinton had remarked that 'he should get Don a desk and chair in the East Wing of the White House'. ${ }^{39}$

Where Cook remained a figure behind the scenes, Russell - in some respects in a tradition pioneered by Casey - took a good deal of trouble to address (if not always court) the many constituencies in the US. His principal focus was undoubtedly economic. As a contemporary commentator observed regarding his appointment, it 'clearly reflects [Keating's] conviction that Australia's relationship with the US has entered a crucial new phase in which trade and economic policy will play a role as important as strategic security was during the Cold War'. ${ }^{40}$

\footnotetext{
35 Michael Cook, Letter to the Editor, New York Times, 1 July 1989.

36 Michael Cook, 'Deadline for Boat People', Washington Post, 21 June 1990, p. A18.

37 Tony Wright, 'Keating Adviser to be US Envoy', Sydney Morning Herald, 12 June 1993, p. 1; Mike Seccombe and Tony Wright, 'The Don: Keating's Hard Man Goes to Washington', Sydney Morning Herald, 17 June 1993, p. 11.

38 Neal Blewett, Cabinet Diary, Wakefield Press, Kent Town, 1999, p. 45; John Edwards, Keating:

The Inside Story, Penguin Books, Ringwood, 1996, pp. 287-90.

39 Keating, Engagement, pp. 92, 45.

40 Wright, 'Keating adviser to be US envoy', p. 1.
} 
Eschewing some of the conventions of regular diplomacy, Russell was not afraid to volunteer frank remarks to American audiences on the difficult task of trade reform. Although the plan to form the NAFTA was originally seen in Canberra as a move towards exclusionary trading blocs, Russell soon saw that a failure on Clinton's part to win Congressional support for NAFTA would considerably weaken the President's standing just as he was due to host the first APEC leaders' meeting in Seattle, and voiced his fears. ${ }^{41}$ Later in the year, Russell played a part in Cairns Group lobbying in Washington in an attempt to convince the US that agricultural subsidies were damaging the agricultural industries of the member countries. ${ }^{42}$ Although (along with Trade Minister Peter Cook) he had managed to extract an undertaking from US Trade Representative Mickey Cantor to restrain the use of its Export Enhancement Program (EEP) that subsidised grain exports, the US had subsequently struck a deal with France, which allowed both parties to continue parallel practices. ${ }^{43}$

The Ambassador's focus on Asian trade issues was thoroughly on display in 1994. In that year, economic tensions between the US and Japan reached unprecedented heights. With the failure of the US-Japan Framework Talks conducted by Clinton and Prime Minister Hosokawa, Washington revived Super 301 (1974 Omnibus Trade Act) to mandate retaliatory trade actions and a trade war loomed. Don Russell was prominent in warning against the attendant risks, and even went as far as criticising the harshness of US tactics. ${ }^{44}$ The US was also in dispute with China on human rights issues, with consideration being given to withdrawing China's Most Favoured Nation (MFN) status unless there were undertakings in Beijing to accept international standards. Russell was reported to have addressed a closed briefing for members of Congress on policy towards China, arguing the case for retention of MFN and suggesting that the Australian approach - then recently developed - of pursuing a parallel human rights dialogue with Beijing

41 Pilita Clark, 'Awkward in Aspen: Don the Diplomat', Sydney Morning Herald, 27 September 1993, pp. 1, 4; Pilita Clark, 'Jittery World at Free Trade, Protectionism Crossroads', Sydney Morning Herald, 16 November 1993, p. 11.

42 Pilita Clark, 'US Hints at Compromise on Subsidies', Sydney Morning Herald, 2 December 1993, p. 10.

43 Pilita Clark, 'Farm Compromise to Cost Australia Dearly', Sydney Morning Herald, 9 December 1993, p. 7.

44 Ben Hills, 'Japan Digs in for Trade War with US', Sydney Morning Herald, 17 February 1994, p. 1; Pilita Clark, 'Christopher Gives Pledge on Cheap US Wheat', Sydney Morning Herald, 4 March 1993, p. 1. 
might improve relations while also assuaging domestic critics. ${ }^{45}$ In the preparations for the APEC meeting that embraced the Bogor targets for regional trade liberalisation, Russell's embassy played an important role in the consultations between Clinton and Keating that ensured the US would take the lead, working hard to overcome some last minute wobbles on the 2010/2020 liberalisation targets (for industrialised and developing economies respectively). ${ }^{46}$

The year 1994 was also one in which the US considered legislation to institutionalise the outcomes of the Uruguay Round of the GATT. Australia's greatest concern was whether promised restraints on the use of the EEP, and also of its equivalent for dairy products, the Dairy Export Incentive Program (DEIP), would remain. Russell vigorously lobbied Cantor to stick to a verbal undertaking to this effect. ${ }^{47}$ In the event, Congress allowed the EEP to continue, but under new restraints.

Returning to Canberra for the 1994 AusMin, Russell addressed the National Press Club, giving a positive and sometimes amusing overview of the Australia-US relationship. In response to a question suggesting otherwise he was quick to insist that Australia's 'new role in the region' was 'of great interest' to the US where policymakers, he claimed, respected Australian knowledge. While emphasising the seriousness of the tensions between Japan and the US on trade as well as accepting the American premise that many sectors of the Japanese market were effectively closed, Russell took the view that these differences would ultimately be resolved. ${ }^{48}$

Yet the trading rules established in 1994 produced less surety than the Australian Government and its ambassador had anticipated. In 1995 tensions rose over increased DEIP expenditures. ${ }^{49}$ Then the EEP was employed to offer cheap wheat to China; just at the time there was a bilateral dispute between Washington and Beijing over issues including

45 Pilita Clark, 'Australia asks America to Renew China's Low-Tariff Trade Status', Sydney Morning Herald, 21 May 1994, p. 15.

46 David Lague and Pilita Clark, 'Keating, Clinton Put Trade Strategy in Place', Sydney Morning Herald, 2 September 1994, p. 2.

47 Pilita Clark, 'US Offers Sympathy but no Guarantees on Subsidies', Sydney Morning Herald, 28 September 1994, p. 6.

48 Don Russell, speech, National Press Club, Canberra, 9 March 1994, National Library of Australia (NLA), Canberra.

49 Pilita Clark, 'Dairy War Looms Over US Subsidies', Sydney Morning Herald, 1 January 1995, p. 1. 
intellectual property. ${ }^{50}$ An exasperated Russell went on the record to point out the inconsistency involved: 'It seems a bit strange if you are trying to be a bit stiff with the Chinese that you offer them cheaperthan-cheap wheat ... It is a big gift to the recipient. ${ }^{51} \mathrm{He}$ also found time to defend Australia's policy on East Timor and sought to explain Australia's opposition to French nuclear tests. ${ }^{52}$ However, perhaps the limits of the relationship with Washington were best illustrated by the Kanimbla incident. Australia had sent a naval crew to pick up one of two former US Navy landing ships that had been purchased; the Pentagon supplied an admiral and Russell attended the handover ceremony that had been arranged. At the last moment, it was discovered that Congress had failed to sign off on the transfer, and was then headed for recess; no amount of pressure from the White House could overcome the delay. It took months to resolve the problem. ${ }^{53}$

Unlike his immediate peers, Russell found a later occasion to reflect at length on the nature of the Australia-US relationship, offering commentary in 2007 especially on differences regarding trade that were undoubtedly informed by his experiences in Washington. $\mathrm{He}$ characterised the pattern of trading linkages in the following terms:

Australia's traditional export relationship is based on Australia's comparative advantage in the production of agricultural products and natural resources. On the face of it, this should provide Australian industry with attractive market opportunities. The [US] market is relatively open and attractive to low-cost producers. However, many key Australian exports are covered by quotas and other barriers to trade. Unfortunately, export industries such as wool, sugar, and dairy, where Australia is a highly efficient producer and where there is scope to expand production, are the very industries most heavily protected in the United States. This keeps Australia's trade negotiators active, but over the years such activity has not produced major gains for Australia. The result has been constant friction and irritation between the two countries. ${ }^{54}$

50 Pilita Clark, 'US Wheat Offer “Gift” for China', Sydney Morning Herald, 9 February 1995, p. 9. 51 Russell, quoted in David Sanger, 'US to Sell China More Wheat Despite Trade Rift', New York Times, 8 February 1995, pp. D1, D7.

52 Letters to the Editor, New York Times, 8 June 1994, p. A24, also 17 July 1995, p. A12.

53 Tony Wright, 'Bungle leaves Sailors Shipshape, Shipless', Sydney Morning Herald, 30 June 1994, p. 2.

54 Don Russell, 'Economic and Business Aspects: An Australian Perspective', in Jeffrey D. McCausland et al. (eds), The Other Special Relationship: the United States and Australia at the Start of the 21st Century, Army War College, Strategic Studies Institute, Carlisle, Pennsylvania, 2007, p. 217. 
In a remark that may be taken as a personal reflection, Russell added: 'Australians often are shocked over the lack of consideration afforded Australia when it comes to market access for traditional Australian exports and the [US] willingness to protect its industries in such a blatant way. ${ }^{55}$

On the decision to pursue an FTA with the US, though Russell noted the advantages that might be gained by the existence of close security relations, he was under no illusions that this connection would result in many material gains: 'U.S. negotiators have become expert at using the intransigence of the American Congress and the importance of the U.S. market to extract concessions from other countries while giving up little, if anything.' Nevertheless, there were positive lessons to be learned. For a figure associated with the favourable appraisal of Australia's traditional bureaucratic practices and the virtues of their need to remain insulated from excessive or partisan external pressures, ${ }^{56}$ Russell's experience in trade negotiations evidently convinced him that the exigencies of working closely with the US demanded different strategies. He concluded that the approach and resources of the Department of Foreign Affairs and Trade were insufficient to the task of dealing with the US, finding in the preparedness of US trade negotiators to harness the resources and input of business and the private sector a strategy that Australia might advantageously emulate. ${ }^{57}$

\section{The ambassadors: John McCarthy, Andrew Peacock, Michael Thawley}

Russell was succeeded by John McCarthy, another polished product (Cambridge) who was returning to the city of his birth where he had also served twice previously. By the end of his diplomatic career, McCarthy's seniority and standing can be gauged by the fact that he had held all the ambassadorial posts that mattered. An early responsibility was to explain the rationale behind the Agreement on Maintaining Security (AMS) with Indonesia, despite having been given no prior notice of its impending announcement, a predicament he shared with his Indonesian

55 Ibid.

56 Parliament of Australia, Don Russell: 'The Role of Executive Government in Australia', Papers on Parliament, No. 41, December 2003, retrieved 1 December 2014, www.aph.gov.au/ senate/ / /link.aspx?_id=0C347E23897C4885BB8B5E5875D21141\&_z=z.

57 Russell, 'Economic and Business Aspects', pp. 224, 226-7. 
counterpart in Washington. Canberra subsequently sent a delegation led by Michael Thawley to explain the AMS to the State Department. Meeting with Winston Lord, Assistant Secretary of State for East Asian and Pacific Affairs, and Stanley Roth, Senior Director for Asian Affairs at the National Security Council, McCarthy was made aware of American displeasure of their complete lack of information regarding this development. ${ }^{58}$ Coming into the position at the end of the Keating era, McCarthy's consummately professional approach undoubtedly facilitated Washington's understanding of the shift in the government's attitude towards the US relationship that was then the product of the domestic political cycle.

McCarthy remained in the post into the Howard Administration, his tenure including Howard's first prime ministerial visit to Washington. He then moved to Jakarta after the department's original choice for the post, Miles Kupa, was denied agrément as a result of an in-house assessment he had written that was critical of Suharto's New Order (which, in the event, was only to last until 1998). McCarthy was somewhat less visible than his predecessor, partly because of his status as a professional diplomat, but also as a product of the fact that - with the completion of the Uruguay Round and the creation of the World Trade Organization (WTO) - there was a strong expectation that clearer rules were beginning to emerge that would lead to more harmonious management of bilateral trade differences. Accordingly, McCarthy maintained the trade and Asia focus of his predecessor, the stress on the latter necessitated by Washington's preoccupations at the time with the Balkans. However, his speeches also contained more than a few references to lamb export quotas. His previous postings had provided the basis for a firm grasp of the importance of Congress where he engaged consistently to promote Australia's interests.

He worked to accommodate the new priorities that emerged in Canberra's approach to the alliance. As he later observed: 'There was ... a desire by the new Coalition Govt. to upgrade the security aspects of the relationship. Washington thought it was fine anyway, but agreed they would train a few more marines in $\mathrm{Oz}$ if we really wanted that. ${ }^{159}$

58 John McCarthy, seminar, Alfred Deakin Research Institute, 2 October 2014.

59 John McCarthy, personal communication, 23 August 2014. 
Such were the beginnings of the current US military presence in Darwin. McCarthy did not serve his full term, leaving in early 1997 to make way for his successor. ${ }^{60}$

In 1997, the precedent set by Richard Gardiner Casey, Percy Spender and Howard Beale was followed by the dispatch of Andrew Peacock (Ambassador 1997-99), former foreign minister and leader of the opposition. ${ }^{61}$ Interestingly, McCarthy had served as his private secretary when he was foreign minister. With his long business and social connections with the US, Peacock was particularly skilful in maintaining a guest list of prominent figures in Washington, though there is no suggestion that his relationship with Shirley MacLaine was pursued for diplomatic and media advantage (though it seems to have had that effect). Without Peacock in Washington it is hard to imagine how Howard would have had the opportunity to sit next to the actress at a Foreign Policy Association dinner in New York in 1997.62 Peacock also found time to pursue his passion for racing, owning a racehorse and regularly visiting the track.

In 1999 Peacock was required to appear before the US International Trade Commission to argue the case against the American industry's demand for restrictive quotas to be placed upon Australian and New Zealand lamb imports. ${ }^{63}$ The Prime Minister was due to visit Washington in July, and with exquisite timing the Clinton Administration announced early that month that a new tariff rate would be imposed upon lamb imports, in addition to setting a quota on the basis of 1998 import levels.

When Howard arrived in Washington shortly afterwards, Peacock was able to organise a glittering array of talent at a barbecue at the embassy, the guest list including Secretary of State Madeleine Albright; US Federal Reserve chair, Alan Greenspan; the Mayor of Washington, Tony Williams; and the Secretary of the Interior, Bruce Babbitt. Among the distinguished Australian residents in the US was World Bank President James Wolfensohn. In his talks with the President, however, the Prime Minister could make no progress on mitigating the blow to the lamb

60 Peter Edwards to John McCarthy, interview, 25 June 2001, NLA, Canberra.

61 Jennifer Hewett, 'Mr Peacock Goes to Washington', Sydney Morning Herald, 28 September 1996; Jennifer Hewett, 'Punting with Peacock', Sydney Morning Herald, 21 June 1997, p. 5.

62 Jennifer Hewett, 'Shirley Catches Up on the Snooze', Sydney Morning Herald, 2 July 1997, p. 1.

63 Jennifer Hewett, 'Washington Bleats About Lamb Imports', Sydney Morning Herald,

27 February 1999, p. 25; John Howard in Commonwealth Parliamentary Debates, House of Representatives, 3 June 1999, p. 5990. 
industry, despite his forceful presentation of the Australian case. ${ }^{64}$ As a sign of the slow but steady evolution of the global trading order, the issue was eventually resolved not by bilateral diplomacy but through the dispute resolution procedures of the WTO.

In September 1999, shortly before he left his post, Peacock helped in Washington to focus American attention on the East Timor issue. According to Howard, he worked with Richard Holbrooke, US Ambassador to the UN, who advised him - with Holbrooke's Bosnian experience in mind - of the importance of a strong mandate for any international force that would enter the territory. ${ }^{65}$ In the event, at the UN Australia insisted upon a 'Chapter VII' mandate for INTERFET - that is, the mandate conferred by the UN Charter, Chapter VII, providing for action with respect to threats to the peace, breaches of the peace, and acts of aggression.

Peacock's replacement was Michael Thawley, who though a career diplomat and bureaucrat had been very close to Howard as foreign policy adviser and was thus, to an extent, a conservative equivalent of Russell. When Howard made his visit to Washington in 2001, it was noticed that while the flamboyant bon viveur Peacock could only manage two members of Clinton's Cabinet at his barbecue for the Prime Minister, no fewer than six of Bush's Cabinet, along with Vice-President Dick Cheney, attended Thawley's equivalent gathering. While an early media profile described him as 'media shy', he impressed journalists as being extremely focused on marshalling the support of American players in order to maximise the prospects of an FTA:

$[\mathrm{H}] \mathrm{e}$ has relentlessly focused on securing a free-trade agreement with the US, helping build a coalition of 120 business groups supporting a deal and calling on members of Congress until they grew tired of him. If there was any criticism of $\mathrm{Mr}$ Thawley it was that he had been at times 'too energetic' in his advocacy, said one US official, who has heard as much about the glories of free trade with Australia as he can stand. ${ }^{66}$

64 Michelle Grattan, 'Barbeque, Then Lamb Beef with Clinton', Sydney Morning Herald, 12 July 1995, p. 5; Michelle Grattan, 'Washington Power Party Puts Andrew in the Pink', Sydney Morning Herald, 13 July 1999, p. 2; Jennifer Hewitt, 'Mr Peacock Rules Washington', Sydney Morning Herald, 17 July 1999 , p. 37.

65 John Howard, Lazarus Rising. A Personal and Political Autobiography, HarperCollins, Sydney, 2010, p. 349.

66 Gay Alcorn, 'Free Trade Loser, Barbecue Winner', Sydney Morning Herald, 12 September 2001, p. 10. 
With an FTA on the agenda (to be realised in 2004), a new era of mutual economic exchange beckoned, though in the interim Thawley found himself making the same arguments as his predecessors on such vexed issues as lamb exports. Giving evidence in 2000 to the US International Trade Commission, he was quoted as arguing forthrightly that ' $[\mathrm{t}]$ he import restrictions invited questions from many Australians about the sincerity of the US position on international trade'. He posed the question: 'Is the United States in favour of free trade only for itself and not for others?'67

In the event, Thawley's evident affinity with Bush and his circle rendered him an ideal appointment for the transformation of the alliance that was to be the product of the September 11 terrorist attacks. Australia's direct invoking of ANZUS has been attributed to his advice. The destabilisation of the entire Middle East was the longer-term result of Bush's policies, as became manifest in events from 2014 .

There are two further and final points to ponder regarding this brace of Australia's emissaries. Two - Cook and Thawley - are Geelong Grammar School 'old boys' and Peacock attended Scotch College. If this referent is a measure of membership of the old money elite, then they qualify. A consideration of their subsequent activities throws some additional light on their personal trajectories, and perhaps also on the perspectives they brought to bear on their diplomatic roles. After his retirement from the Department of Foreign Affairs and Trade, McCarthy remained directly active in the foreign policy community, serving as President of the Australian Institute of International Affairs from 2009 to 2015. Following a break during the Howard years, mostly in the financial world abroad, Russell returned to Canberra to serve as a departmental head. Cook retired to the UK, where he had once been Deputy High Commissioner; he has however, in recent years, published some personal commentary on the history of Australian foreign affairs. Having retired from Australian service, Peacock and Thawley took up residence in the US, respectively in Texas and in Washington, the former to attend to his many business interests, the latter to join a fund management entity. While Peacock subsequently had little to say on issues of current policy, Thawley has contributed to the Australian debate - delivering for example the 2005 Annual Menzies Lecture at Monash University - 
and has also funded an Australia-US research scholarship at the Lowy Institute. He returned to Canberra to head the Department of the Prime Minister and Cabinet in November 2014 in the final months of the Tony Abbott prime ministership.

\section{Conclusions}

The bookend years noted at the beginning suggest a significant transition in Australian foreign policy behaviour, namely, from a growing priority on regionalism with an economic focus to a return to the security embrace of the US alliance. From what is on the public record of the activities of Australia's diplomatic emissaries in this period, their roles conformed in some cases proactively - to the requirements of this transition. Cook was familiar with the Republican 'hard men' at the time of Australia's participation in the first GulfWar, but this was deemed to be of growing irrelevance with the advent of the Clinton Administration and the rise of the regionalist agenda. Russell's close personal relationship with the Prime Minister, as much as his academic and policy backgrounds and activist style, made him a good advocate for Keating's economic objectives. McCarthy's charm and professionalism were indispensable in the transition phase when the Howard Administration was finding its feet in international affairs. Peacock's flamboyance and personal connections with the American business elite gave the embassy a prominence it would not otherwise have had. Thawley's Republican connections served him well especially with the turn to the preoccupation with terrorism.

Yet several cautions are in order for the effectiveness of representation in these years to be correctly judged. For all his cultivation of the media and the Washington policy community, Russell had to battle against the same commercial interests with which Cook had engaged. Despite his visibility, Peacock was still in the same position. With the invoking of ANZUS and the later negotiation of the Australia-US Free Trade Agreement, Thawley's difficulties were hardly apparent in the period under review. However, he was later to be embarrassed by his obligation to defend before a Congressional committee the conduct of the Australian Wheat Board (AWB), which, the Volcker Inquiry subsequently found, had paid - from July 1999 - an estimated AU $\$ 29$ million to Saddam Hussein's regime in violation of UN sanctions in order to guarantee a continued market for Australian wheat. 
If, finally, events in the years 1991 and 1998 are chosen as significant markers of the underlying trend, the narrative takes on quite a different aspect. As has been noted, in 1991 the Hawke Government committed forces to the First Gulf War; in 1998 the Howard Government sent an SAS military contingent to the same theatre in preparation for possible coalition action against the Saddam Hussein regime. Despite all the talk of seeking security in Asia and planning for defence selfreliance, the dispatch of expeditionary forces in support of great power projects remained the preferred response. To be sure, in both of these cases UN legitimation was a factor, yet when it was absent in 2003 it did not prevent resort to the same strategy. The 'Sydney Statement' of 1996 may have been presented as a breakthrough in alliance security cooperation, but it is worth recalling that the 'Agreement Between the Government of Australia and the Government of the United States of America Concerning Reciprocal Defense Procurement' was originally a proposal of Labor Defence Minister Robert Ray in 1995; though it was signed as a memorandum at the AusMin of that year it did not clear Congressional approval until after the start of the new millennium. And a further note of continuity can be detected in the outcome of the issue that appeared set to embarrass all those involved in the AWB scandal; despite harsh words while in opposition - including making the point that the issue was potentially damaging to relations with the US - the Rudd and Gillard administrations did not pursue the matter once they occupied the government benches. 
This text is taken from Australia goes to Washington: 75 years of Australian representation in the United States, edited by David Lowe, David Lee and Carl Bridge, published 2016 by ANU Press, The Australian National University, Canberra, Australia. 